\title{
Seizing global warming as an opportunity
}

Preparations for the next global meeting on climate change, to be held in Kyoto in December, provide countries with an excuse to devise sound economic policies that make sense both scientifically and environmentally.

B ritain's Labour party has always been slightly distrustful of the environmental movement. The reasons are not difficult to discern. One is that environmentalists tend to criticize the outcomes of those very processes - namely industrial and economic growth - on which the party's traditional supporters in the Labour movement rely as heavily for their welfare as do their employers. A second is that, historically, concern for the environment has many of its roots among landowning classes, keen to conserve it for their personal use. Red and green are colours that often do not sit well together.

US politicians and others therefore have cause for scepticism at the apparent conversion of the new Labour government to the environmentalist cause. Britain is planning to send an unprecedentedly highpowered delegation, headed by the prime minister, Tony Blair, to the United Nations meeting in New York later this month being held to mark the fifth anniversary of the Earth Summit, held in Rio de Janeiro in 1992. Officials say that Blair and his colleagues intend to take an aggressive approach, urging other countries to follow Britain's example in curbing greenhouse-gas emissions, for example, and chastising the United States for dragging its feet on policies to limit the hazards of man-made climate change (see page 640).

Those on the receiving end of these messages will no doubt be quick to point out that Britain's ability to set an example is as much the result ofluck as of judgement. If, as expected, Britain becomes with Germany the only two major European states to meet a commitment made at Rio to reduce greenhouse-gas emissions to their 1990 levels by the end of the decade, this is primarily thanks to economic — not environmental - considerations that have prompted a shift from coal to gas as a source of energy. Indeed, it is ironic that Blair's ability to take the high ground is due partly to the success of the former prime minister, Margaret Thatcher, in crushing the power of a group that had been among Labour's strongest supporters, the coal miners.

\section{Integrated approach}

But justified scepticism must not be allowed to overshadow the main thrust of the new UK government's approach to climate change and other related environmental issues: that strategies designed to curb the unwanted side-effects of economic and industrial growth will only succeed if they are integrated into a broader patchwork of political and social goals. Domestically, Blair is seeking to do this by linking climate change policy to other priorities, sensible in themselves, such as energy conservation and a viable strategy for public transport. Internationally, a workable agreement on curbing greenhouse-gas emissions will only emerge if this takes into account the legitimate desire of developing countries for high levels of economic growth.

High among the countries learning its lesson the hard way is Japan. As host to the next meeting of signatories of the UN Framework Convention on Climate Change, due to be held in Kyoto in December, Japan will be expected to take a key role in devising a viable international strategy for implementing the emission cuts that are expected to be agreed at the meeting. But its own thinking on this issue appears hide- bound by those government officials, particularly in the Ministry of International Trade and Industry, who appear locked into a commitment to the pursuit of economic growth at almost whatever cost (see page 641). A failure to shift this perspective will only weaken Japan's standing, both in Kyoto and in subsequent negotiations.

The ability of Blair and other politicians - including Japan's prime minister, Ryutaro Hashimoto - to set a new course depends heavily on good science. If agreement is reached, as hoped, at Kyoto on relatively ambitious targets for reducing greenhouse-gas emissions, much of the credit must go to the work of the Intergovernmental Panel on Climate Change (IPCC). The panel's hard-fought consensus, published in 1995, that "the balance of evidence suggests that there is a discernible human influence on global climate", has established a clear reality that cannot be wished away, as even lobby groups representing the fossilfuel industries have now, reluctantly, come to admit.

\section{Science still needed}

And science's role is far from over. Much remains to be done in refining the models that are increasingly used as a guide to policy initiatives. One need is for credible models of regional impacts of global warming that are able adequately to characterize threats in terms of major perturbations in weather patterns, rather than single parameters such as a rise in temperature or sea levels. Inevitably, governments will be more tempted to take action if their voters are convinced of the selfinterest in doing so; one of the biggest hurdles facing Clinton and his vice-president, Al Gore, will be to persuade the Senate to ratify any agreement reached in Kyoto, for precisely this reason.

But, even more than good science, also needed are imaginative solutions that promise both to achieve desirable environmental and social goals, and to be politically 'saleable'. Here Japan is already winning high marks in some quarters for a proposal for a two-tiered strategy to reduce greenhouse-gas emissions. While developed countries would be required to make immediate cuts, developing countries would be allowed to postpone any action until they have reached a previously agreed per capita level of carbon emissions. Although this would mean abandoning the 'flat-rate' reductions that many environmentalists claim is essential, others see in such a solution both an economic and a political logic that makes it attractive.

The greatest danger facing Blair and his colleagues, including Germany's chancellor Helmut Kohl, is that they will place an excessive confidence in the work of climatologists, using the apparent simplicity of broad conclusions to legitimate essentially non-scientific policies (as has happened with BSE). After all, some elements of the science will undoubtedly change - remember the 'limits to growth' debate - and policy must not be locked in concrete. Their greatest opportunity is that a growing sense of crisis over global warming will focus minds on the need to rethink our use of energy and other resources, and to accept the pain that this will inevitably require. If they can get this message across to a global audience, then both Clinton and Hashimoto will have reason to be grateful. 